women who kill. The perspective offered is narrow in some parts, and the topics covered are limited. Those that are considered, however, are generally explored thoroughly.

Overall, I do not feel that this is a useful book for trainees, unless they have a particular interest in the psychodynamic understanding of violent, disturbed women. Even with that interest, the reader, particularly if a trainee, should be aware of the controversial nature of some of the views presented and the significance of material omitted.

Motz states that her aim had been to present a range of cases of female violence and to offer a model for understanding these cases. I believe that she has achieved this, and, if one is aware of the book's limitations, one will not be disappointed. Issues relating to female violence and allied service developments are extremely topical at this time, and there is increasing interest in the psychopathology of women who offend. To a certain extent, this book has missed the opportunity offered by such interest but it still gives a fascinating, although limited, insight into women's mental health.

Fiona L. Mason Consultant Forensic

Psychiatrist, St Andrew's Hospital, Billing Road,

Northampton NNI 5DG, UK

\section{Prophets, Cults and Madness}

By Anthony Stevens \& John Price.

London: Duckworth. 2000. 246 pp. $£ 18.00$

(hb). ISBN 0715629409

Ultra-Darwinists think that anything biological that exists must be advantageous to the survival of an organism or at least to the propagation of its genes, or at the very least must once have been so. And this, of course, includes anything 'psychobiological'. This Panglossian viewpoint none the less imposes a duty on its adherents to demonstrate the alleged advantage. And with a little ingenuity it can usually be done. Even if you do not believe, as Stevens $\&$ Price do, that psychology and psychiatry have been revolutionised in the past decade by the advent of evolutionism, and that as a result we now 'have a pretty good idea' why people become depressed, phobic, jealous and sadomasochistic, their attempt to explain the 'survival' of schizophrenia is a tour de force.

Incomplete penetrance and phenotypic plasticity allow the existence of the famous formes frustes of schizophrenia. So the same nasty genes that determine the negative symptoms - lethargy, emotional blunting and suchlike - can, in certain circumstances (note the envirome creeping in), turn the positive symptoms - hallucinations and delusions - into creative innovation and charismatic leadership.

Stevens \& Price do not argue that biblical prophets or modern cult leaders such as David Koresh of the Branch Davidians had schizophrenia: only that they were 'schizophrenicish'. Such people often arise in situations of economic hardship or social instability and tend to attract the downcast and the disaffected. They preach with apocalyptic vision and succeed in commanding extraordinary loyalty from their followers, even to the point of sexual slavery and human self-sacrifice. Moreover, the force of their personal conviction, however bizarre, becomes the focus for a breakaway society to be formed. They may provide the impetus for a revitalisation of culture. Therefore, unlike those categorised as having schizophrenia, they have a higher than average chance of spreading their genes.

But if, as Stevens \& Price tell us, the prophecies of cult leaders are rarely innovative and usually consist of an amalgam of preexisting religious clichés, it is difficult to see how they could revitalise anything. I begin to get lost. Certainly I have failed to

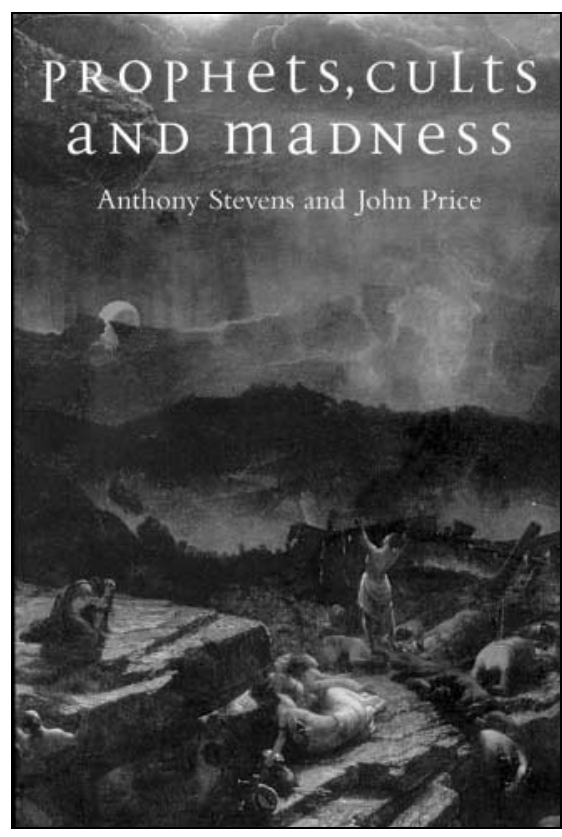

do justice to the authors' scholarship, their synthesis of the relevant literature and their nicely written text. I do recommend you read the book for yourself.

Stephen Wilson Consultant Psychiatrist and Psychotherapist, Department of Psychotherapy, Warneford Hospital, Oxford OX3 7JX, UK

\section{Obsessive-Compulsive Disorder}

Edited by Mario Maj, Norman Sartorius, Ahmed Okasha \& Joseph Zohar. Chichester: John Wiley \& Sons. 2000.308 pp. $€ 60.00$ (hb). ISBN $047187163 X$

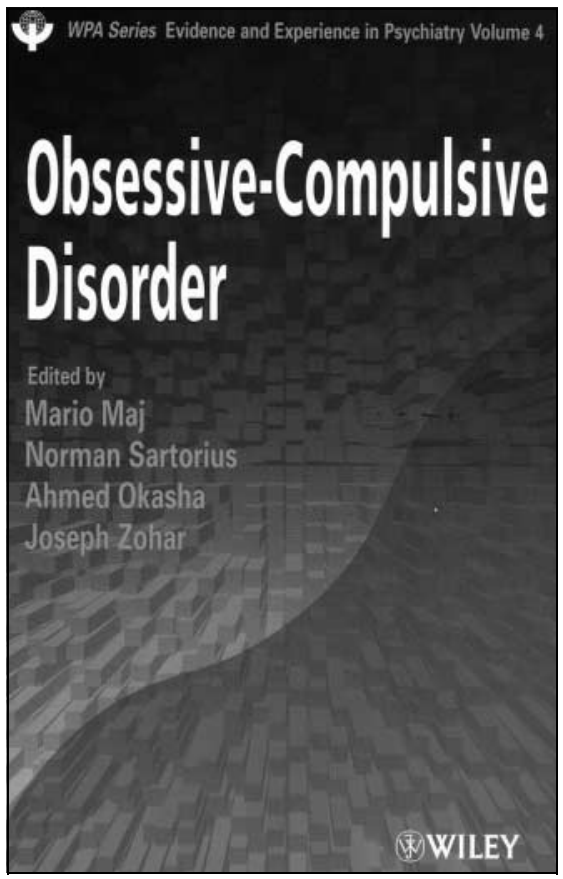

This book is part of the World Psychiatric Association (WPA) series on Evidence and Experience in Psychiatry. Two years ago the WPA undertook to produce a review of areas of psychiatry in which there have been significant advances of knowledge, with the view that bringing together worldwide experts to review the current research evidence would result in further improvements in the provision of care. Obsessivecompulsive disorder (OCD) is one of the chosen areas. Over the past 20 years there has been a burgeoning interest in OCD, resulting from the recognition that it is not the extremely rare disorder it was once thought to be. Indeed, it has a worldwide prevalence of about $2 \%$ in the adult population, making it the fourth most common psychiatric disorder. 